\title{
ナノエマルションの設計と化粧品機能 \\ Preparation Technique for Nanoemulsions and Their Application for Cosmetics
}

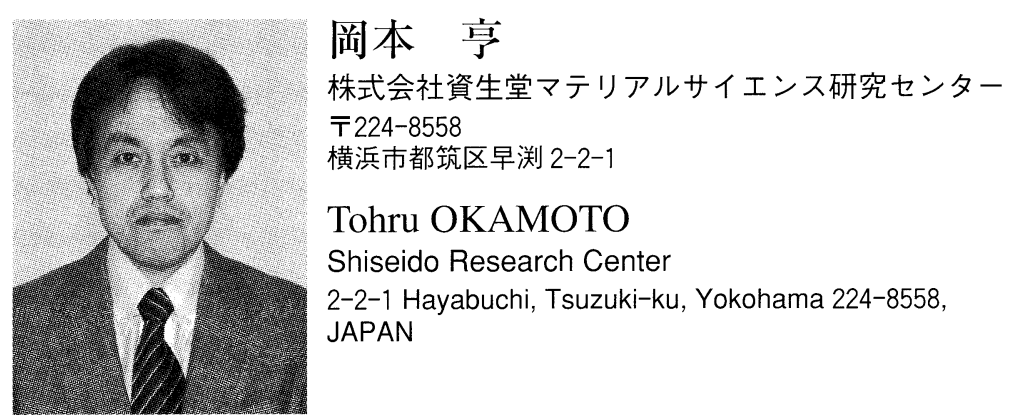

\begin{abstract}
In this article, two emulsification techniques providing nanoemulsions, which are condensation method and dispersion method, are described. Nanoemulsions by condensation method was prepared by cooling single phase microemulsions to temperature below the solubilization phase boundary. Key process of the second dispersion method was the homogenization of coarse emulsions with water phases containing large amounts of water-soluble solvents by a high-pressure homogenizer. Then the application and function of nanoemulsions for cosmetics are reviewed. An aqueous wax nano-dispersion was prepared through the cooling procedure of microemulsions which was made above the melting temperature of wax. The formula of the dispersion can be used for hair spray and hair mist having a low viscosity. $\mathrm{O} / \mathrm{W}$ cream containing surfactant and amphiphile also became transparent with a low viscosity by the reduction of emulsion droplet size. This technology can give lotion type cosmetics with an excellent function that can be found in $\mathrm{O} / \mathrm{W}$ cream.
\end{abstract}

Key words: Nanoemulsion, Microemulsion, Dispersion, Condensation, Cosmetics

\section{1 はじめに}

エマルションは，水と油のように互いに溶け合わない 液体の一方を微粒子として他の液体中に分散させた系と 定義される。エマルションは熱力学的に不安定な系であ るため，経時でクリーミング，凝集，合一などの過程を 経て，最終的には二相に分離する。エマルションの不安 定化は複雑なプロセスで進行するが，分散媒と分散質の 密度差によって生じるクリーミングは，凝集や合一の引 き金になりやすい。クリーミングを防止するためには， エマルションの微細化が有効であり, さらに $100 \mathrm{~nm}$ 程 度まで乳化粒子を微細化することができれば化粧水のよ うな低粘度の剂形でも安定に保つことができる。エマル ションの安定化の観点から，微細エマルションに関する 研究が精力的に行われてきた。

エマルションの調製法には，「分散法」と「凝集法」 がある。凝集法は, 均一な溶液あるいは可溶化状態の油
分を何らかの方法で析出, 成長させてエマルションを調 製する方法であり，分散法は大きな分散質を剪断力で細 かく分散する方法である。分散法におけるエマルション の微細化は油/水界面の生成を通して進行するが，水と 油の界面に存在する界面張力のため分散相を微細化する ためには界面張力に逆らって仕事をする必要がある。転 相乳化法や HLB 温度乳化法，D 相乳化法などは，界面 化学的に油/水界面張力の低い系をつくり乳化すること で，強力な剪断力をかけることなく低いエネルギーで微 細なエマルション粒子を調製する手法である。一方，高 圧ホモジナイザーなどの強力な剪断力を有する乳化機を 用いると, $100 \mathrm{~nm}$ 程度の微細エマルションを容易に調 製できる。本稿では，これらの方法では実現できなかっ た $100 \mathrm{~nm}$ 以下の粒子径をコントロールしたナノエマル ションの調製方法について紹介し, 処方設計の考え方と 応用例について述べる。 


\section{2 ナノエマルションの調製法}

\section{$2 \cdot 1$ 凝集法によるナノエマルションの調製}

Fig. 1 は代表的な界面活性剂/油/水系の状態図と相図 を用いた微細エマルションの調製プロセスを示す。転相 乳化法（a）は界面活性剤を油に溶解させそこに攪拌し ながら水相を加えていくことにより微細なエマルション 調製する方法である1)。水を加えていく過程で逆ミセル， ラメラ液晶相， O/D エマルションを通過し O/W エマル ションの領域へ連続的に変化する。液晶相を通過する際 に界面張力が小さくなり微細エマルションが得られる。 Fig. 1(b) は HLB 温度乳化法である ${ }^{2-4)}$ 。POE 型のノニ オン界面活性剂の HLB は温度とともに変化し，高温で は疎水的となり $\mathrm{W} / \mathrm{O}$ エマルションを生成し, 温度の低 下とともに親水化し 3 相領域を経て $\mathrm{O} / \mathrm{W}$ エマルション に転相する。3 相領域では界面張力が著しく低下するこ とから微細エマルションが得られる。これらの方法は Fig. 1(c) の一般的な乳化方法に比べて, 微細なエマル ションを調製できたが $100 \mathrm{~nm}$ 以下のナノエマルション の調製は困難であった。

凝集法によるナノエマルションは Fig. 1(d) に沿って 調製される。可溶化限界曲線と最点曲線の間の可溶化領 域において油分を大量に可溶化した領域がマイクロエマ ルションである。中島らはマイクロエマルションを生成 した後室温まで急冷して相図上の二液相領域に移行させ ることでマイクロエマルションの液滴の粒子サイズを 持ったナノエマルションが調製できることを示した ${ }^{5,6,7)}$ 。 マイクロエマルションを冷却し，二液相領域へ移行した 際，可溶化限界温度の近傍では二液相エマルションの安 定性が悪く粒子径が増大し白濁するが, 適切な油分や界 面活性剤を選択し，冷却速度など調製条件を工夫するこ とで濁度变化なく二相領域に移行できる。可溶化限界温

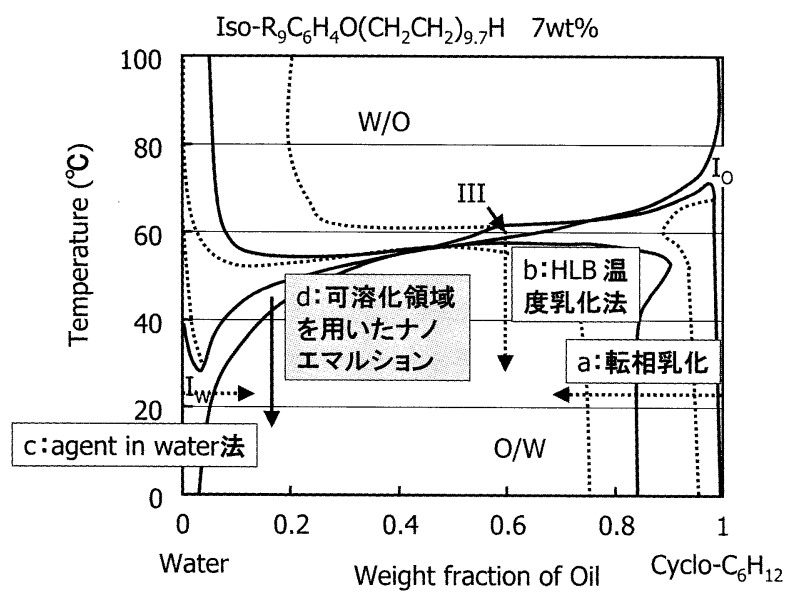

Fig. 1 微細乳化プロセスの比較
度付近の一液相 $\mathrm{O} / \mathrm{W}$ マイクロエマルションの濁度が二 液相領域でそのまま維持されることは，ミセルの粒子径 がそのままナノエマルションの粒子径になることを意味 している。可溶化ミセルの大きさは界面活性剤と油の重 量比によって決まることから，ナノエマルションの粒子 径を界面活性剂と油の重量比によってコントロールする ことができる(Fig. 2) ${ }^{5)}$ 。Fig. 2 においてスクワラン系で 油/界面活性剂 $=3.5$ 以上で粒子径が直線から大きく解離 しているのは，この組成ではすべての油分を可溶化でき ないためである。

分散法でエマルションを微細化する場合，界面を生成 するため大きなエネルギーを必要とするが，この方法は 自発的に油滴が生成している可溶化領域を用いることで 攪挥条件などの影響を受けないというメリットがある。

\section{$2 \cdot 2$ 分散法によるナノエマルションの調製}

油滴を微細化すると新たな界面が生成する。新たな界 面には，水相中の界面活性剤が単分子吸着しエマルショ ンを安定化する。したがって，微細化によって生じた界 面に処方中の界面活性剂のすべてが吸着した状態がエマ ルションの最小粒子径と考えられ，それ以上界面積を拡 大（粒子サイズを微細化）することは安定性の観点から 困難である6)。Fig. 3 に流動パラフィンとポリオキシエ チレン（30）オレイルエーテル $\left(\mathrm{C}_{18} \mathrm{E}_{30}\right)$ を合計 $30 \%$ 配 合した系において両者の重量比を変えて高圧ホモジナイ ザーを用いて乳化し，その油分と界面活性剤の重量比と 粒子サイズの関係を示した。Fig. 3 の実線はそれぞれの 乳化処方について界面活性剂の単分子吸着に打ける分子 占有断面積から計算した最小粒子径を示す。この線上に あれば界面活性剤を最も効率的に利用した理想的な乳化 状態である。Fig. 3 より界面活性剤に対して油分の配合 量が高い（目標粒子径が大きい）系では容易に最小粒子 径まで到達できるが，微細化のために界面活性剂の組成

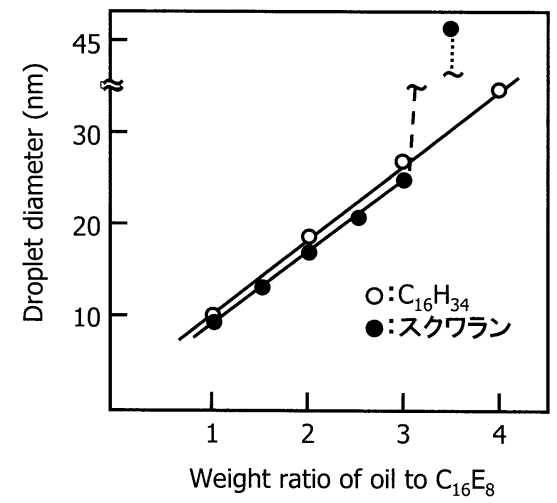

Fig. 2 油と $\mathrm{C}_{16} \mathrm{E}_{8}$ の重量化による粒子径コントロール 


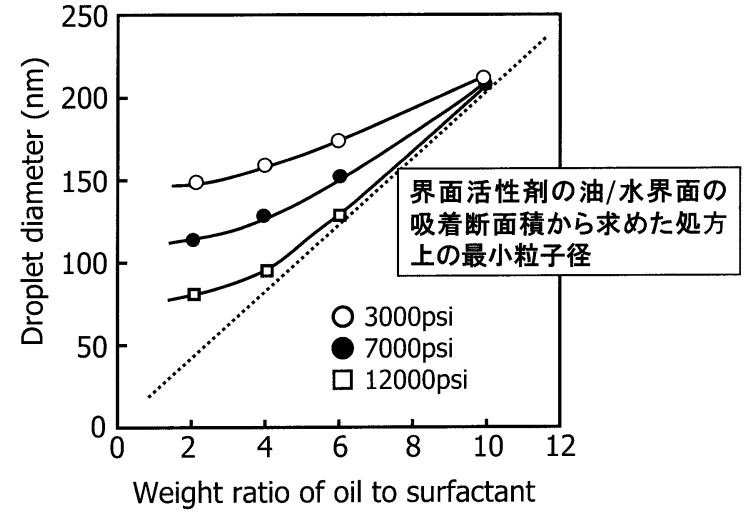

Fig. 3 油と界面活性剤の重量比と乳化粒子径 乳化処方: 流動パラフィン $+\mathrm{C}_{18} \mathrm{E}_{30} 30 \mathrm{wt} \%$, 水 $70 \mathrm{wt} \%$

を高めると粒子サイズは直線から上方に乘離することが わかる。剪断力を高めるとこの乘離は小さくなるが機械 力に限界があるため, $100 \mathrm{~nm}$ 以下の粒子サイズで理想 的な乳化を行うことは困難であったが, 中島らは, 水溶 性溶媒を水相に高濃度添加配合した $\mathrm{O} / \mathrm{W}$ エマルション を高圧ホモジナイザーで処理することで微細化の効率が 高まることを見出した ${ }^{7,8)}$ 。Fig. 4 は流動パラフィン $(20 \%), \mathrm{C}_{18} \mathrm{E}_{30}(10 \%)$ および水溶性溶媒を含む水溶液 (70\%) からなる O/W エマルションを高圧ホモジナイ ザーを用いて乳化した結果である。水溶性溶媒としてグ リセロールと $1,3-$ ブタンジオールを用い, 水溶液中の水 溶性溶媒濃度とエマルションの粒子サイズをプロットし た。水溶液中のグリセロール，1,3-ブタンジオールの濃 度の上昇とともにエマルションの粒子サイズは小さくな り, 水溶性溶媒の添加がエマルション粒子の微細化に効 果的であることがわかる。

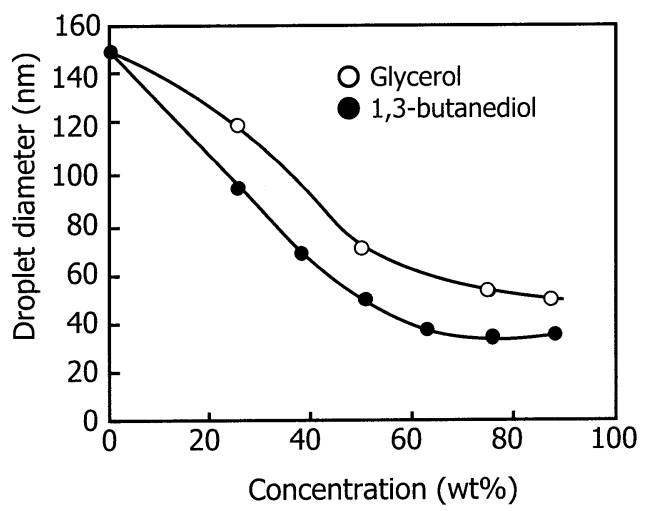

Fig. 4 水相中の水溶性溶媒の濃度と乳化粒子径の関係 乳化圧：3,000 psi

乳化処方：流動パラフィン $20 \mathrm{wt} \%, \mathrm{C} 18 \mathrm{E} 3010 \mathrm{wt} \%$, 多価アル コール

水溶液 $70 \mathrm{wt} \%$

\section{3 ナノエマルションの安定性}

\section{$3 \cdot 1$ 界面活性剤の構造}

一般的な $\mathrm{O} / \mathrm{W}$ エマルションの合一安定性は，同一の HLB であれば界面活性剤の分子サイズが大きいほど，ア ルキル基が同一であれば親水基が大きい（HLBが高い） ほど向上する ${ }^{9)}$ 。凝集法によるナノエマルションも一液 相領域（可溶化領域）から二液相領域に移行する際に合 一を生じやすい状態を経由するため，合一安定性を高め ることが有効である。また，可溶化限界温度の近傍で は，エマルションの安定性が悪化することから保証すべ き温度領域の上限と可溶化限界温度が離れていることが 重要であり量点の高い親水性界面活性郕が適している ${ }^{6)}$ 。

\section{$3 \cdot 2$ オストワルドライプニング}

ナノエマルションの安定性には油分の影響を注意する 必要がある。Fig. 5 は， $\mathrm{C}_{16} \mathrm{E}_{8}$ を 10\%，各種油を $10 \%$ と

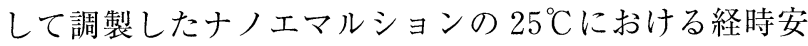
定性を示す。ドデカンは数時間で粒子径が増大するが炭 化水素油の炭素数の増大に伴い経時安定性は向上し, 流 動パラフィン，スクワランでは半年以上も濁度変化や粒 子径変化が認められなかった。ナノエマルションの粒子 径の経時による増大は，オストワルドライプニング (Ostwald ripening) によるものと考えられる ${ }^{10)}$ 。オスト ワルドライプニングは，粒子径が異なる粒子間において Kelvin 則で表される溶解度に差異が生じ，小さな油滴か ら大きな油滴に向け油分子の拡散が起こる現象である。 液滴の半径の違いに基づく溶解度差は次式で表される。

$\mathrm{RT} \ln \left(\mathrm{C}_{\mathrm{r}} / \mathrm{C}_{\infty}\right)=2 \gamma \mathrm{V} / \mathrm{r}$

（1）において, $r$ ：液滴の半径, $\mathrm{C}_{\mathrm{r}}$ : 半径 $\mathrm{r}$ の時の夜

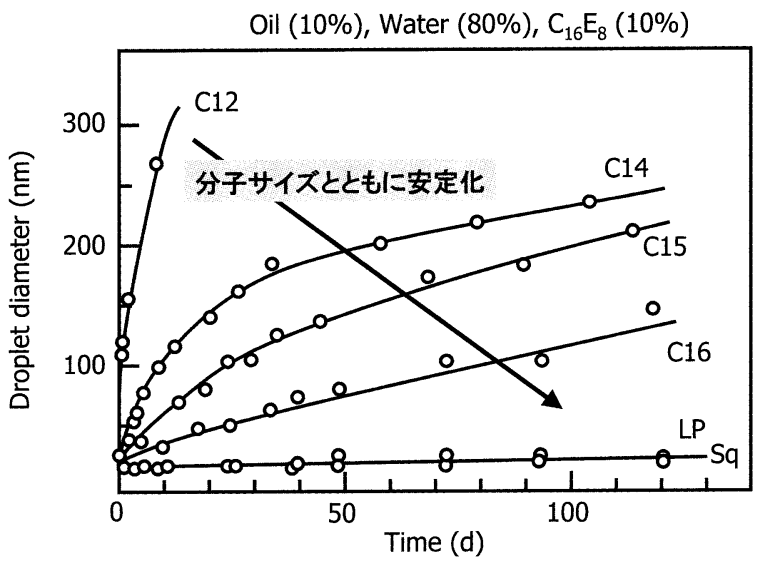

Fig. 5 炭化水素油の分子サイズとナノエマルションの安定 性 
滴の溶解度, $\mathrm{C}_{\infty}$ : 半径 $\infty$ の時の液滴の溶解度, $\gamma$ : 界面 張力, $\mathrm{V}$ : 分散相のモル体積, $\mathrm{R}$ ：気体定数, $\mathrm{T}$ ：絶対 温度である。（1）式より，粒子径に分布があると溶解度 差が生じるが, 粒子径が小さいほど影響は大きく通常の エマルションではオストワルドライプニングは問題にな りにくい。また, 粒子サイズが変化する速度は水相中に おける油の単位時間当たりの移動量に依存する。油の水 相中での移動量は油の水への溶解度に依存するため, Fig. 5 の結果は炭化水素油の水への溶解度に関係してい ると推察される。オストワルドライプニングを防ぐため にはスクワランなどの安定性の良好な油分を少量添加す ることが有効である (Fig. 5) ${ }^{5,6)}$ 。炭素数が小さなドデカ ンは Kelvin 則により粒子径の小さな油滴から大きな油 滴に拡散するが, 炭素数が大きいスクワランはほとんど 移動しない。したがって, 時間の経過とともに粒子径の 小さな油滴にはスクワランが, 大きな油滴にはドデカン が濃縮される。この時, 粒子間にスクワランとドデカン のケミカルポテンシャルの差が生じ, Raoult 則によって Kelvin 則と逆の方向にドデカンを移動させるように働 き, それ以上の油の移動は停止し粒子径も一定に保たれ ると考えられる。

\section{4 ナノエマルションの活用事例}

\section{$4 \cdot 1$ ワックスナノディスパージョン}

凝集法によるナノエマルションの調製技術を発展させ た事例として，ワックスナノディスパージョンを紹介す る。カルナウバワックスやキャンデリラワックスは, 毛 髪につやの付与や高い整髪力などからへアケア製品に広 く用いられているが, 融点が高く, 結晶析出などの問題 が生じやすいため製剤化が難しくスティックやクリーム 状の剂形に限定されていた。松浦らは, HLB 9〜12 程度 のノニオン界面活性礼とベタイン系の雨性界面活性剤の 混合系にワックスを可溶化して，急冷することにより $50 \mathrm{~nm}$ 程度のワックスナノディスパージョンが調製する 技術を開発した ${ }^{11,12)}$ 。種々のノニオン界面活性剂 $10 \%$ と 両性界面活性剂（ココイルアミドプロピルベタイン） 5\%にカルナバワックス 10\%を可溶化し, 可溶化の可
否, および冷却後の状態を検討したところ, 直鎖, 分岐 いずれも HLB 9 程度のノニオン界面活性剤でカルナバ ワックスを可溶化できたが, 可溶化状態から急冷すると アルキル鎖長の短い界面活性剂では冷却過程で合一し白 濁を生じた。冷却過程では合一に対して不安定な状態を 通過するため，合一安定性の良好な分子サイズの大きい ノニオン界面活性剤を選択するべきである。

ワックスナノディスパージョンは液状であるため, 従 来のワックスエマルションでは実現が難しかった流動性 のある製剤（ヘアミスト，ヘアローションなど）へ応用 できる。Fig. 6 はワックスナノディスパージョンを配合 したへアフォームと従来の固形状ワックスエマルション を塗布した時の毛髪表面の SEM 写真である。ワックス ディスパージョン配合ヘアフォーム（右）は毛髪表面に 均一にワックスが薄膜状に付着しているのに対し，固形 状ワックス（左）は毛髪表面に不均一に付着しているこ とが分かる。また，前者は毛髪に塗布しやすく，べたつ きのない使用感を有していた。従来固形状でしか調製で きなかったワックスエマルションを，乳化技術によりナ ノディスパージョンとすることで，流動性のあるへアミ スト，ヘアローションなど剤形が可能となり，新しい外 観，使い心地，機能を付加することができた事例であ る。

\section{$4 \cdot 2 \alpha$ ゲルを用いたクリーム処方のナノエマルション}

エモリエント性の高い化粧水を調製しようとした場 合，乳液・クリーム処方をそのまま低粘度化することが 必要となる。一般に，O/W クリームは，両親媒性物質/ 界面活性剂/油/水系で構成され，両親媒性物質と界面活 性剂が水相中で $\alpha$ ゲルを形成している。 $\alpha$ ゲルは，界面 活性剂と高級アルコールのような両親媒性物質が親油基 を六方晶構造に配列したラメラ液晶に類似した構造を とっている。 $\alpha$ ゲルはラメラ液晶より親油基の自由度が 制限された状態であり，それらがネットワーク構造を作 ることで系全体を増粘固化させている。化粧品では, ア ニオン性,ノニオン性界面活性剂と高級アルコールの組 合せがスキンケア化粧品に，カチオン界面活性剂と高級

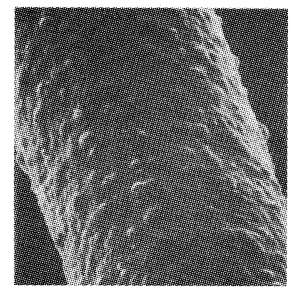

Wax emulsion

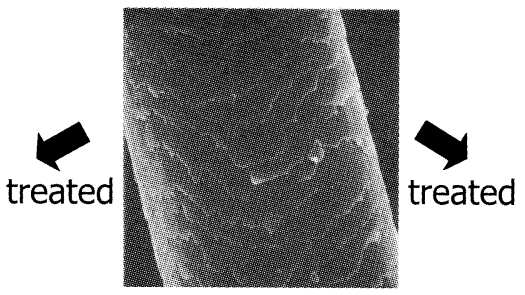

Normal hair

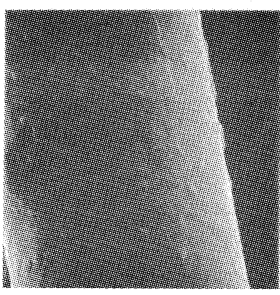

New wax nano-dispersions

Fig. 6 ワックスナノディスパージョンとワックスエマルションの毛髪への塗布状態の比較 


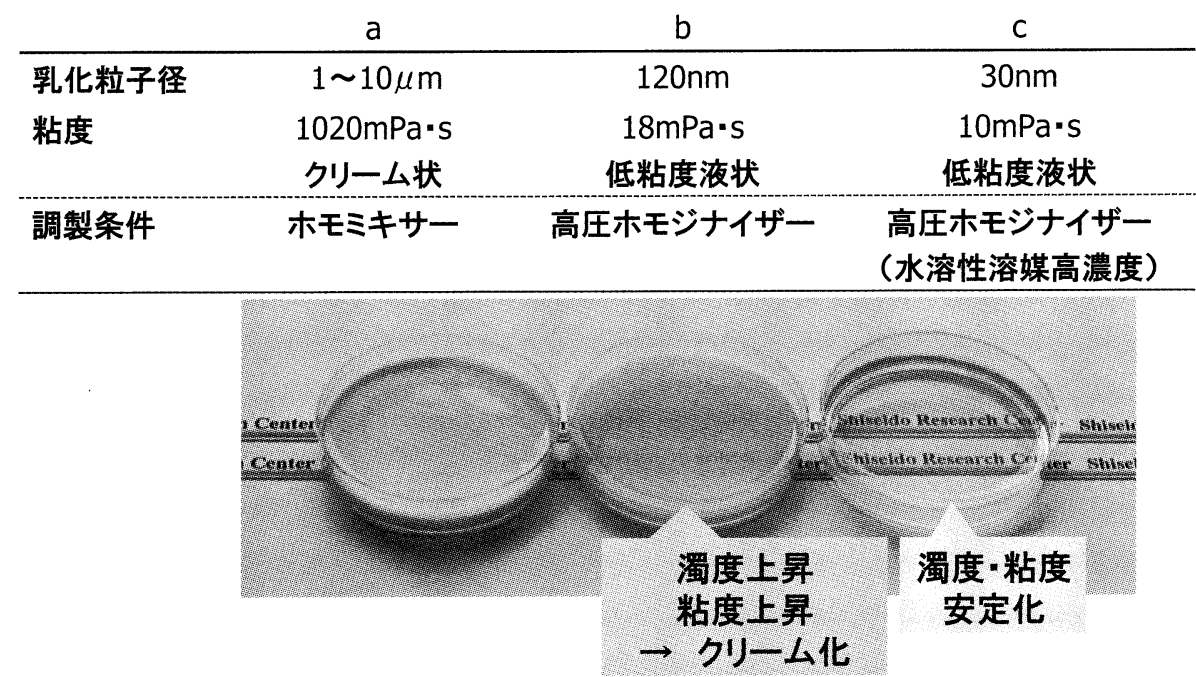

Fig. $7 \alpha$ ム゙ルリーム処方によるナノエマルション

アルコールの組合せがヘアリンスに用いられている ${ }^{13.14) 。 ~}$ さらに， $\alpha$ ゲルはエマルションの安定化だけでなく，使 用感触や皮膚に対する有用性へも寄与している ${ }^{15,16)} 。 こ$ のことは，エモリエント性を付与するために両親媒性物 質と界面活性剤を配合し製剂化すると増粘した製剂しか 調製できないことを意味している。そこで $\mathrm{O} / \mathrm{W}$ クリー ムの処方にナノエマルションの調製技術を応用して低粘 度安定な製剂開発を試みた ${ }^{17-19)}$ 。

カチオン界面活性剤として塩化ステアリルトリメチル アンモニウム (STAC), 高級アルコールとしてステア リルアルコール $(\mathrm{C} 18 \mathrm{OH})$ を用い，流動パラフィンま たはジメチルポリシロキサンを油分として種々の粒子サ イズのエマルションを調製した。通常の調製方法で増粘 した製剤（Fig. 7(a)）をゲルの融点以上で高圧ホモジナ イザー処理を行うと，低粘度の製剤となる（Fig. 7(b)） がこれは経時でクリームに戻ってしまった。一方，Fig. 7 (c) のように $30 \mathrm{~nm}$ 程度までエマルション粒子を微細 化すると低粘度が維持できた。一連の現象は， $\alpha$ ゲルの 存在状態によるものであることを DSC 測定などから明 らかにされている。Fig. 8 は，ジメチルポリシロキサン を油分としたときの，エマルションの粒子サイズと DSCチャートを示す。粒子サイズが大きい時は，カチ オン界面活性剂/高級アルコール/水系の相転移ピークと ほぼ同じ挙動を示したが，粒子サイズの微細化に伴い $\alpha$ ゲルのピークは縮小し低温側に新たなピークが出現し た。 $\alpha$ ゲルの相転移エンタルピーと粒子サイズの関係か ら，粒子サイズの微細化に伴い生じた新しい界面に $\alpha$ ゲ ルの成分が吸着し，水相中の $\alpha$ ゲルの相転移エンタル ピーが縮小したと考察された。この結果，水相における $\alpha$ ゲルの分散物が漸減し，ネットワークの再構築を起こ
しにくくなり粘度上昇を防止できたと考えられた ${ }^{17,18)}$ 。 脂肪酸セッケン/脂肪酸/高級アルコール/油/水系で ナノエマルションを調製し，化粧品機能の評価を行っ た ${ }^{19)}$ 。基剤処方を Table 1 に示す。ナノエマルションは, 化粧水様の基剂で低粘度のニュートン流動を示したが, 実際に塗布するとクリームに類似した擬塑性流動に変化 した。これは，水分揮散とエマルションの破壊に伴い $\alpha$ ゲルが放出され流動特性が変化したものと推察された。 この基剤のスキンケア効果を調べたところ，塗布後の皮 膚からの水分蒸散を抑制する作用は従来の乳液と同等の 効果を有し（Fig. 9)，さらに実験的に作成した肌荒れに 対する改善作用も良好であった。この基剤は保存時は $\alpha$ ゲルの成分がエマルション表面に吸着され安定化し，皮 膚に塗布するとエマルションの破壊に伴い $\alpha$ ゲルが生成 し処方本来の機能が生じたと考えられた。

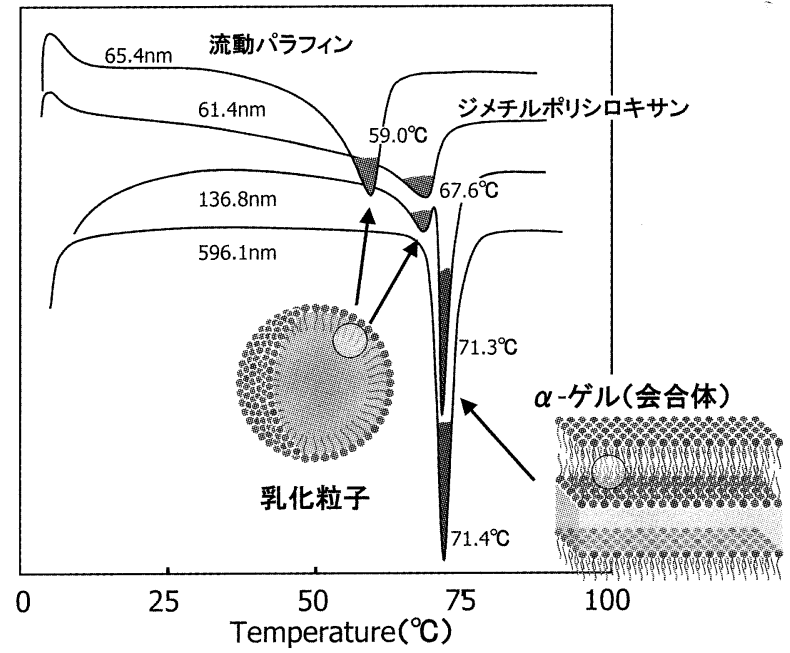

Fig. 8 乳化粒子の微細化と相転移挙動 
Table 1 基剤処方

\begin{tabular}{|c|c|c|c|}
\hline & 化粧水 & 乳液 & $\begin{array}{c}\text { 新規製剂 } \\
\text { (ナノエマルション) }\end{array}$ \\
\hline ベヘニルアルコール & - & - & 1.2 \\
\hline ステアリルアルコール & - & - & 0.3 \\
\hline セチルアルコール & - & 1.0 & - \\
\hline ベヘニン酸 & - & - & 0.5 \\
\hline ステアリン酸 & - & - & 0.5 \\
\hline POE(15) ステアリルエーテル & - & 1.0 & - \\
\hline $\mathrm{KOH}$ & - & - & 0.13 \\
\hline 流動パラフィン & - & 5.0 & 5 \\
\hline ワセリン & - & 5.0 & - \\
\hline セチル 2-エチルヘキサノエート & - & 5.0 & - \\
\hline グリセリン & 10 & 5.0 & 10 \\
\hline 1,3-ブチレングリコール & - & 5.0 & 5 \\
\hline 水 & to 100 & to 100 & to 100 \\
\hline
\end{tabular}

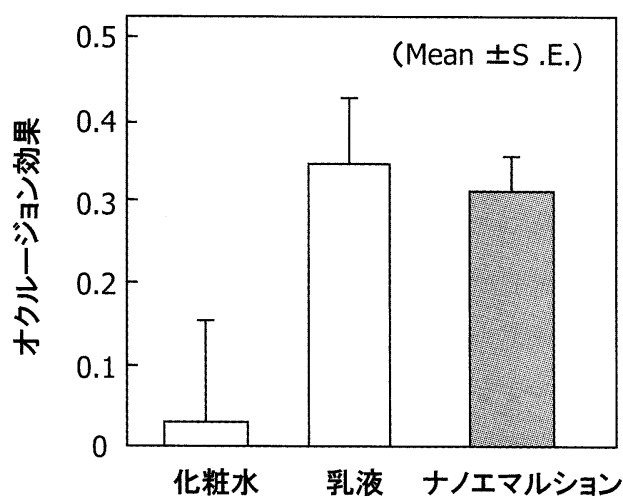

Fig. 9 基剤のオクルージョン効果の比較 オクルージョン効果：(TEWL(経皮水分蒸散量：塗布前) TEWL(塗布 2 時間後)) / TEWL(塗布 前)

\section{5 おわりに}

ナノエマルションの研究はエマルションの安定化の観 点から行われ, 可溶化領域を用いる方法や高圧乳化機を 用い効率よく微細化する方法が開発されてきた。これら は, 少ない界面活性剂で多くの油を含む半透明, 低粘度 で安定な化粧品用のローションの調製を可能にしただけ でなく, 乳液・クリーム処方を化粧水のような物性に保 つ技術やワックスナノディスパージョンの新しい商品開 発につながっている。今後は，さらにナノエマルション であることを商品にどのように活用するかが重要になる と思われる。今後の技術開発に期待したい。
文献

1) H. Sagitani, J. Am. Oil Chem. Soc., 58, 738 (1968).

2) K. Shinoda \& H. Saito, J. Colloid Interface Sci., 26, 70 (1968).

3) K. Shinoda \& H. Saito, J. Colloid Interface Sci., 30, 258 (1969).

4) H. Saito \& K. Shinoda, J. Colloid Interface Sci., 32, 647 (1970).

5）友政哲, 河内みゆき, 中島英夫, 油化学, 37, 1012 (1988).

6). 中島英夫, 友政哲, 河内みゆき, J. Soc. Cosmet. Chem. Jpn., 23, 288 (1990).

7）中島英夫, 表面, 36, 39 (1998).

8) H. Nakajima, S. Tomomasa \& M. Kochi, Proc. 1 th. World Congress of Emulsion(Paris), 1, 162 (1993).

9) K. Shinoda \& H. Saito, J. Colloid Interface Sci., 35, 624 (1971).

10) W.I. Higuchi \& J. Misra, J. Pharm. Sci., 51, 459 (1962).

11) E. Matsuura, A. Noda, Y. Shiojima et al., The 21 th IFSCC international congress proceedings, Berlin (2000).

12）松浦恵衣子, 野田 章, 塩島義浩ら, 第 21 回 IFSCC ベルリ ン大会論文報告会講演要旨集, p 34 (2000).

13）山口道広, 野田 章, 日本化学会誌, 1987, 1632 (1987).

14）山口道広, 野田 章, 日本化学会誌, 1989, 26 (1989).

15) T. Suzuki, H. Tsutsumi \& A. Ishida, The 12 th IFSCC international congress proceedings, Paris, 1, 117 (1982).

16) T. Suzuki, H. Tsutsumi \& A. Ishida, 日本化学会誌, 1983, 337 (1983).

17）岡本亨, 安斎伸一, 中島英夫, 第 48 回コロイドおよび界 面化学討論会要旨, p 112 (1995).

18）岡本亨, 安斎伸一, 中島英夫, 第 48 回コロイドおよび界 面化学討論会要旨, p 654 (1995)。

19) Okamoto T., Tomomasa S., H. Nakajima et al., The 18 th IFSCC international congress proceedings, Venezia, 2, 327 (1994). 